\title{
HERPES SIMPLEX VIRUS INFECTION: DISSEMINATION IN ASSOCIATION WITH MALNUTRITION
}

\author{
BY \\ D. MCKENZIE, J. D. L. HANSEN and W. BECKER \\ From the Red Cross Children's Hospital and Departments of Pathology and Child Health, University of Cape Town, \\ and the C.S.I.R. and U.C.T. Virus Research Unit, Department of Pathology, University of Cape Town
}

(RECEIVED FOR PUBLICATION NOVEMBER 11, 1958)

Eight cases of disseminated herpes simplex infection unassociated with infantile eczema have been found at autopsy during the period September, 1957, to April, 1958. All but two of these were grossly malnourished.

Herpetic stomatitis is very much more common than is generally appreciated. Routine studies carried out in our virus laboratory have revealed that many of the more severe and atypical forms of stomatitis are due to the herpes simplex virus, and in the past must have been diagnosed as stomatitis due to Vincent's angina or moniliasis.

While herpes simplex infection usually manifests itself as a lesion localized to the epithelial surfaces of the lips, face and mouth, widespread systemic involvement does from time to time occur. Dissemination in association with infantile eczema (eczema herpeticum or Kaposi's varicelliform eruption) is well known, but in recent years a fulminating illness due to widespread dissemination of the herpes simplex virus, quite unassociated with eczema, has been reported by several investigators.

On histopathological grounds, Hass (1935) suggested that the necrotic liver and adrenal lesions found in a premature infant at autopsy were due to systemic dissemination of the herpes simplex virus. Encephalitis in the newborn due to herpes simplex virus has been recorded by several authors (Smith, Lennette and Reames, 1941; Wildi, 1951; Florman and Mindlin, 1952; France and Wilmers, 1953), hepatic necroses due to the same agent have been described (Quilligan and Wilson, 1951; Zuelzer and Stulberg, 1952; France and Wilmers, 1953; Pugh, Newns and Dudgeon, 1954; Brain, Pugh and Dudgeon, 1957) while necrotic adrenal lesions have been noted in association with eczema herpeticum (Zuelzer and Stulberg, 1952; Brain et al., 1957). With the exception of two cases in Group II of Zuelzer and Stulberg (1952) and one case of Brain et al. (1957), all cases recorded have occurred in the neonatal period. Of interest in our series is that all the children were between 9 and 16 months of age.

\section{Clinical Features}

The clinical features of the eight cases are summarized in Table I. In all save one convulsions occurred before admission, and in all but one there was clinical evidence of gross malnutrition. The one case with proved pneumococcal meningitis falls into a rather different category.

The cerebrospinal fluid in five of the remaining seven cases was examined on admission and was normal. A further specimen of the C.S.F. from Case 5 was examined four days after admission and proved to be abnormal with a protein of $170 \mathrm{mg} . \%$, positive globulin test and 25 lymphocytes but normal sugar content. Autopsy revealed an encephalitis in this instance.

The occurrence of a bleeding tendency in half our cases confirms the similar observation made previously (Zuelzer and Stulberg, 1952).

Virus Studies. Virus studies were undertaken on tissues removed at autopsy from Cases 4, 7 and 8.

Tissue slices were taken from the liver and other organs and stored in separate containers. A suitable portion of each tissue was weighed and ground up to make a $10 \%$ emulsion in Hank's lactalbumen hydrolysate medium (Melnick, 1956), containing penicillin in a concentration of 100 units $/ \mathrm{ml}$., streptomycin $100 \mu \mathrm{g} / \mathrm{ml}$., neomycin $100 \mu \mathrm{g} / \mathrm{ml}$., and mycostatin 25 units $/ \mathrm{ml}$. After centrifugation of the emulsion at 10,000 r.p.m. for 10 minutes, $0 \cdot 1 \mathrm{ml}$. amounts of the supernatant fluid were inoculated into HeLa tissue and/or monkey kidney tissue rollertube cultures. The supernatant fluid was tested for bacteriological sterility and the remainder was ampouled and stored in dry ice. 
TABLE 1

SUMMARY OF CASES

\begin{tabular}{|c|c|c|c|c|c|c|c|c|c|c|}
\hline $\begin{array}{l}\text { Case } \\
\text { No. }\end{array}$ & $\begin{array}{l}\text { Race } \\
\text { and } \\
\text { Sex }\end{array}$ & $\underset{\text { (months) }}{\text { Age }}$ & $\begin{array}{l}\text { Weight } \\
\text { (lb. oz.) }\end{array}$ & Symptoms & $\begin{array}{l}\text { Stom- } \\
\text { atitis }\end{array}$ & $\begin{array}{l}\text { Hepato- } \\
\text { megaly }\end{array}$ & $\begin{array}{c}\text { Signs of } \\
\text { Malnutrition }\end{array}$ & $\begin{array}{l}\text { Con- } \\
\text { vulsions }\end{array}$ & $\begin{array}{l}\text { Other } \\
\text { Findings }\end{array}$ & $\begin{array}{l}\text { Death after } \\
\text { Admission } \\
\text { (days) }\end{array}$ \\
\hline 1 & Col. F. & 16 & 一. & $\begin{array}{l}\text { Arrived O.P.D. in } \\
\text { extremis with severe } \\
\text { stomatitis: died be- } \\
\text { fore admission }\end{array}$ & Yes & 一 & Kwashiorkor & - & 一 & On admission \\
\hline 2 & Col. F. & 12 & 913 & $\begin{array}{l}\text { Diarrhoea and vomit- } \\
\text { ing for } 5 \mathrm{~d} \text {. Convul- } \\
\text { sions, } 1 \mathrm{~d} \text {. }\end{array}$ & N.R. & Yes & $\begin{array}{c}\text { Gross maras- } \\
\text { mus }\end{array}$ & Yes & $\begin{array}{l}\text { Raised serum } \\
\text { sodium and } \\
\text { chloride. Apyrexial }\end{array}$ & 2 \\
\hline 3 & Col. F. & 12 & 1114 & $\begin{array}{l}\text { Diarrhoea and vomit- } \\
\text { ing for } 4 \mathrm{w} \text {. }\end{array}$ & Yes & Yes & Kwashiorkor & Yes & Purpura & 8 \\
\hline 4 & $\begin{array}{l}\text { Native } \\
\text { M. }\end{array}$ & 15 & 14 & $\begin{array}{l}\text { Diarrhoea and vomit- } \\
\text { ing for } 3 \mathrm{w} \text {. }\end{array}$ & Yes & Yes & Kwashiorkor & Yes & Purpura & 7 \\
\hline 5 & Col. M. & 9 & 97 & $\begin{array}{l}\text { Diarrhoea, vomiting, } \\
\text { cough for } 3 \mathrm{w} \text {. Sore } \\
\text { mouth for } 1 \mathrm{w} \text {. }\end{array}$ & Yes & Yes & Malnourished & Yes & $\begin{array}{l}\text { Pyrexia bleeding } \\
\text { tendency }\end{array}$ & 4 \\
\hline 6 & Col. M. & 15 & $20 \quad 13 \frac{1}{2}$ & $\begin{array}{l}\text { Stomatitis for } 3 \mathrm{~d} \text {. } \\
\text { Convulsions for } 1 \mathrm{~d} \text {. }\end{array}$ & Yes & No & None & Yes & Pyrexia & 1 \\
\hline 7 & Col. F. & 12 & 135 & $\begin{array}{l}\text { Sore mouth for } 2 \mathrm{w} \text {. } \\
\text { Convulsions for } 1 \mathrm{~d} \text {. }\end{array}$ & Yes & Yes & Kwashiorkor & Yes & $\begin{array}{l}\text { Pyrexia bleeding } \\
\text { tendency }\end{array}$ & 4 \\
\hline 8 & $\begin{array}{c}\text { Native } \\
\text { M. }\end{array}$ & 14 & N.R. & $\begin{array}{l}\text { Sordes. Pneumo- } \\
\text { coccal meningitis }\end{array}$ & N.R. & N.R. & Malnourished & Yes & - & 17 \\
\hline
\end{tabular}

The tubes were incubated at $37^{\circ} \mathrm{C}$. in a revolving drum and examined each day for cytopathogenic effect. Two serial subcultures were made, using larger inocula of $0 \cdot 2-0 \cdot 3 \mathrm{ml}$. before a specimen was assumed to have no virus present.

Virus titrations were carried out on the stored supernatant fluids from those specimens in which virus had been detected. Tenfold dilutions of the fluids were made in Hank's lactalbumen hydrolysate medium containing $5 \%$ rabbit serum (freed of inhibitor and heat-inactivated), and these were inoculated in $0.1 \mathrm{ml}$. amounts into tissue culture tubes, using three or four tubes per dilution. The results are indicated in Table 2.

Cytopathogenic effect produced by the herpes simplex virus in these cases was striking and distinctive. The virus was identified by a standard neutralization technique using herpes simplex

TABLE 2

VIRUS ISOLATIONS

\begin{tabular}{c|l|l|l}
\hline $\begin{array}{c}\text { Case } \\
\text { No. }\end{array}$ & \multicolumn{1}{|c|}{$\begin{array}{c}\text { Specimens } \\
\text { Examined }\end{array}$} & $\begin{array}{c}\text { Virus } \\
\text { Isolation }\end{array}$ & \multicolumn{1}{|c|}{$\begin{array}{c}\text { Titre } \text { TCID }_{50} \\
/ \mathrm{ml}^{\circ}\end{array}$} \\
\hline 4 & Liver & Positive & Not done \\
\hline 7 & $\begin{array}{l}\text { Liver } \\
\text { Spleen } \\
\text { Lung } \\
\text { Heart, tongue, kidney } \\
\text { adrenal, brain, blood }\end{array}$ & $\begin{array}{l}\text { Positive } \\
\text { Positive } \\
\text { Positive } \\
\text { Negative }\end{array}$ & $\begin{array}{l}10^{8 \cdot 0} \\
10^{3 \cdot 0} \\
\text { Less than } 10^{1 \cdot 0}\end{array}$ \\
\hline 8 & $\begin{array}{l}\text { Liver } \\
\text { Spleen }\end{array}$ & $\begin{array}{l}\text { Positive } \\
\text { Positive }\end{array}$ & $\begin{array}{l}10^{8 \cdot 25} \\
10^{6 \cdot 75}\end{array}$ \\
\hline
\end{tabular}

immune serum prepared in mice, and controls set up under the same conditions with normal mouse serum. In the case of each isolation these virus observations were checked by the production of encephalitis in mice and typical pocks on the chorioallantoic membrane of the developing chick embryo.

Two commercial preparations of gamma globulin were titrated for inhibition of cytopathogenic effect by the herpes simplex virus isolated from Case 7. The one preparation neutralized $50 \mathrm{TCD}_{50}$ when diluted $1 / 1200$, the other when diluted $1 / 1400$. Case 7 received $3 \mathrm{ml}$. of the latter preparation of gamma globulin on the third day before death, and the serum (heat-inactivated) from the autopsy was found to neutralize $50 \mathrm{TCD}_{50}$ only at a dilution of less than $1 / 2$.

Morbid Anatomy and Histology. The autopsy findings are summarized in Table 3 . In six of the eight cases macroscopic lesions were found in the liver. These are so characteristic that in Case 8 , who died of pneumococcal meningitis, the pathologist performing the autopsy was able without hesitation to identify the liver lesion as being due to herpes simplex infection. Where the lesion was not visible macroscopically the histological appearances were such that there was no doubt as to the aetiology.

Tongue. In the majority no resemblance to the 
TABLE 3

SUMMARY OF AUTOPSY FINDINGS

\begin{tabular}{|c|c|c|c|}
\hline $\begin{array}{l}\text { Case } \\
\text { No. }\end{array}$ & $\begin{array}{l}\text { Hepatic } \\
\text { Necrosis }\end{array}$ & $\begin{array}{l}\text { Adrenal } \\
\text { Necrosis }\end{array}$ & Comment \\
\hline 1 & Microscopic & Microscopic & - \\
\hline 2 & Macroscopic & No & Bronchopneumonia \\
\hline 3 & Macroscopic & Microscopic & - \\
\hline 4 & Macroscopic & Microscopic & $\begin{array}{l}\text { Bronchiolitis. Virus isolated } \\
\text { from liver }\end{array}$ \\
\hline 5 & Microscopic & Microscopic & Encephalitis \\
\hline 6 & Microscopic & Microscopic & Round worms ++ \\
\hline 7 & Macroscopic & No & $\begin{array}{l}\text { Infarct of spleen. Virus } \\
\text { isolated from liver, spleen, } \\
\text { lungs }\end{array}$ \\
\hline 8 & Macroscopic & Microscopic & $\begin{array}{l}\text { Pneumococcal meningitis. } \\
\text { Splenic lesions possibly } \\
\text { attributable to herpes } \\
\text { simplex virus. Virus } \\
\text { isolated from liver, spleen }\end{array}$ \\
\hline
\end{tabular}

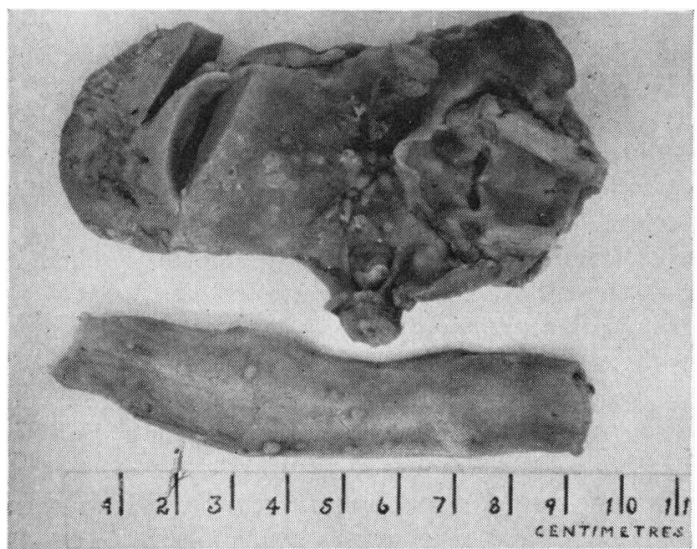

FIG. 1.-Tongue and oesophagus showing hypertrophic lesions caused by herpes simplex virus.

vesicular nature of the original lesion was recognizable. The vesicles had become confluent, and large areas of the surface of the tongue had been replaced by superficial serpiginous ulcers. Occasionally the lesions were more hypertrophic, yellow in colour and slightly raised above the surface (Fig. 1).

Microscopically there was superficial ulceration without penetration into the underlying muscle. The surface epithelium had sloughed away leaving an area of necrosis covered by a fibrinous exudate in which only occasional polymorphonuclear cells were present. At the margin of the lesion characteristic epithelial giant cells were seen mainly lying free in the area of ulceration, and in these and in nuclei of the adjoining epithelial cells nuclear inclusions were visible (Fig. 2).
The first detectable abnormality appeared to be swelling of the epithelial cell nuclei with fragmentation of the chromatin network and loss of basophilic staining, the central portion of the nucleus remaining unstained save for basophilic stippling caused by chromatin fragmentation. The nucleus continued to increase in size and the chromatin and nucleolus became marginated, resulting in an apparent increase in thickness of the basophilic nuclear membrane; at the same time eosinophilic intranuclear inclusion bodies became apparent as rounded globules, some occurring singly and occasionally several in one nucleus. These eosinophilic bodies increased in size and, where multiple, appeared to coalesce so that large eosinophilic bodies almost filled the swollen nucleus with a clear unstained halo between them and the nuclear membrane. At this stage the nucleolus was no longer recognizable and some nuclei were extremely irregular in outline, with the

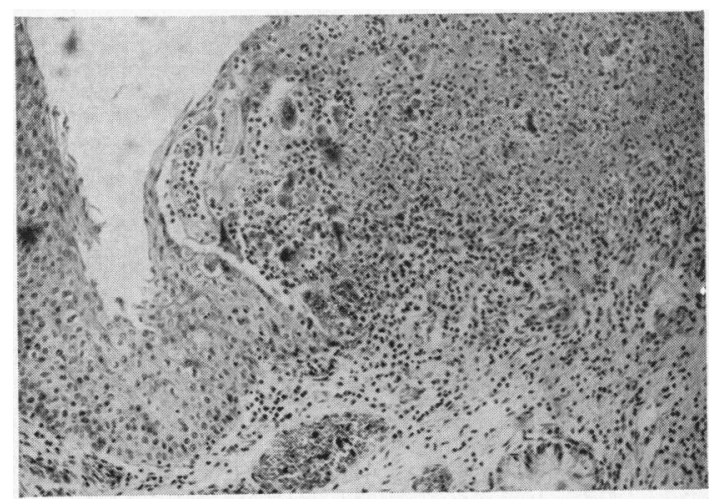

Fig. 2.- Margin of herpetic ulcer in tongue showing epithelial giant cells. H. and E. $\times 90$.

indentations of the nuclear membrane imparting a bizarre appearance to the nucleus (Fig. 3).

In the epithelial cells at the margin of the ulcer a cytoplasmic change also became apparent. There was ballooning of the cell and the cytoplasm lost its eosinophilic staining and became clear. No inclusion bodies were seen in adjacent superficial glands. The earliest stage of the inclusions were seen in the cells next to but outside the ulcer, the final stages prior to destruction of the nucleus being at the very edge of the ulcer.

Oesophagus. The oesophagus was affected in four of the eight cases. In three of these there were punched out ulcers up to $2 \mathrm{~mm}$. in size over the lower third to half of the oesophagus. In the 


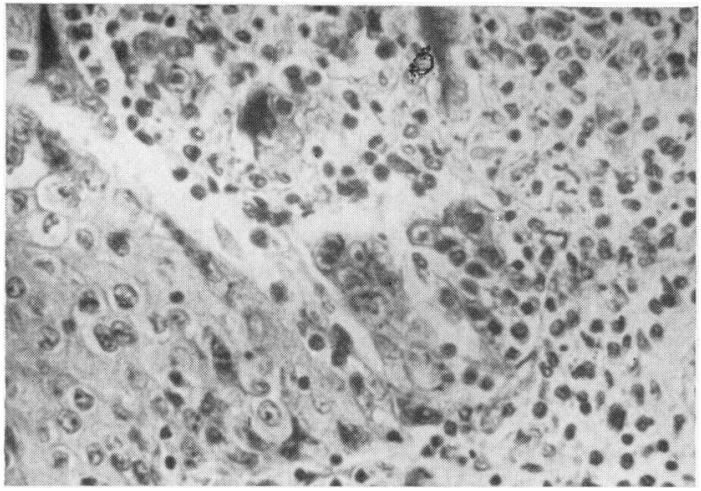

FIG. 3.-Nuclear inclusions in epithelial cells of tongue. $H$. and E. $\times 160$.

remaining case there was a mixed picture of yellow nodules up to $3 \mathrm{~mm}$. in diameter and raised approximately $1 \mathrm{~mm}$. above the surface and small punchedout superficial ulcers up to $1 \mathrm{~mm}$. in size. A small zone of congestion surrounded the nodular lesions and similar lesions were present in the pyriform fossae (Fig. 1).

Microscopically the appearances were very similar to those seen in the tongue, apart from the nodular lesions, which consisted of heaped-up fibrinous exudate with some epithelial cells. No giant cells were seen in our sections but nuclear changes in the epithelium at the ulcer margin paralleled those described in the tongue.

Liver. In six of the eight cases there was a macroscopic lesion of the liver, associated with a gross degree of fatty infiltration. The lesions were so striking that they may be regarded as pathognomonic of herpes simplex infection. Their size varied, presumably with duration, from pin head foci of necrosis just visible with the naked eye to areas up to $3 \mathrm{~mm}$. in size. Unless these had become confluent each was a perfect circle, dead white in colour, with a surrounding zone of hyperaemia or haemorrhage giving a target-like appearance to the whole and sharply demarcating the affected tissue from the surrounding liver parenchyma (Fig. 4). There did not appear to be any regularity of distribution of these lesions in the liver substance, and they were scattered in haphazard fashion both under the capsule and on section. There were no obvious differences between the two lobes in frequency of the lesions. In some cases the lesions were strikingly uniform in size while in others the widely varying size suggested different ages in dissemination and development.

Microscopically the extent of parenchymal in-

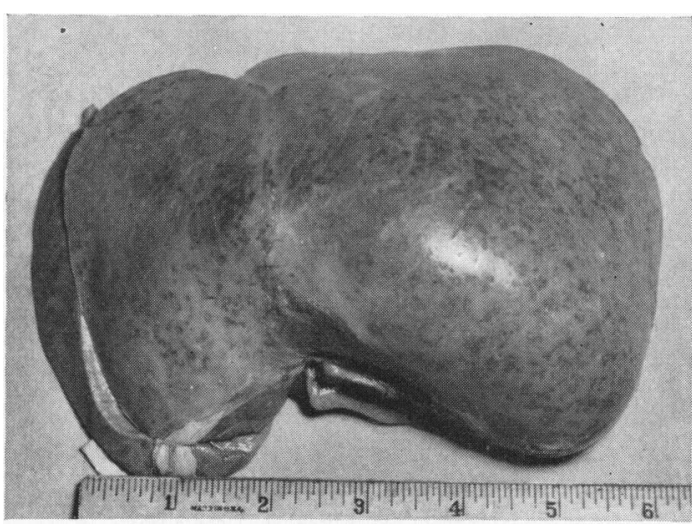

FIG. 4.-Liver showing the characteristic circular areas of necrosis.

volvement varied from $10 \%$ in the least involved to $75 \%$ in the most severely affected (Fig. 5). In most the lesions were multilobular though in the smaller and presumably earlier lesions they were lobular and situated more in the mid- and peripheral zones than centrally.

Whether large or small the necrotic focus was infarct-like to the extent that both parenchyma and stroma were equally destroyed. In the centre usually only nuclear remnants were apparent, but in the early lesions in addition haemorrhages were evident with red cells lying free in the area of necrosis. The necrotic area merged abruptly into surviving liver parenchyma in which the only detectable abnormalities were in cell nuclei. There was no evidence of inflammatory reaction or of proliferation of liver cells, but there was dilatation of sinusoids over a narrow zone surrounding the lesion.

In more extensive and presumably older lesions the area of necrosis was far more extensive, and red cells were not recognizable as such in the centre,

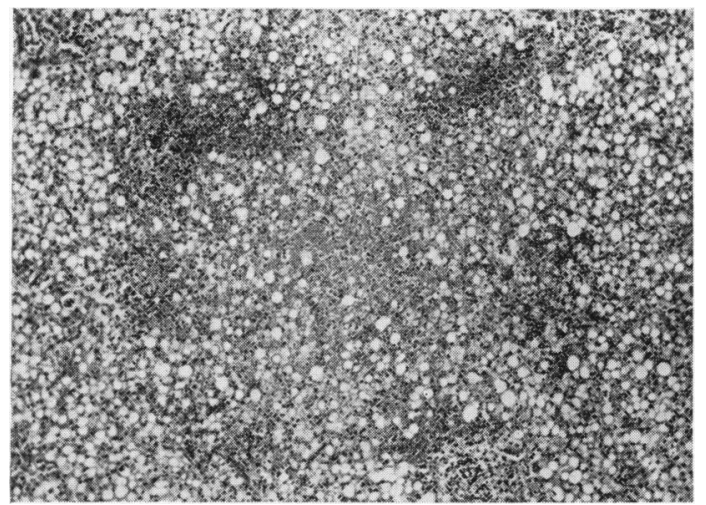

FIG. 5.-Liver: the large central area of necrosis is surrounded by haemorrhage. H. and E. $\times 150$. 
but formed a homogeneous pool of laked blood merging with the necrotic background.

The feature of greatest histopathological interest was the presence of intranuclear inclusion bodies (Fig. 6). There appeared to be two patterns of development of these structures. Whether the different forms of nuclear change seen were all intermediate between normal nuclei and nuclei with fully mature inclusion bodies or whether varied pathways of development took place was impossible to say. However not all stages, nor even similar stages, were recognizable in all sections. It is reasonable to believe that the more mature inclusions are likely to be in the centre and the earlier stages at the periphery. For this reason the peripheral cells are taken as the starting point for the purpose of describing the nuclear changes.

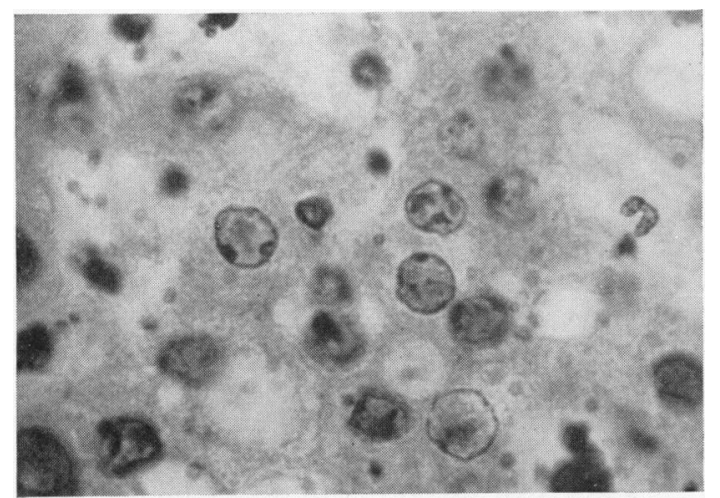

FIG. 6.-Intra-nuclear inclusions in liver cells. H. and E. $\times 800$.

What was regarded as the earliest indication of infection was a swelling of the nucleus and loss of staining density. The chromatin was fragmented and appeared as basophilic stippling of the nucleoplasm which was otherwise unstained; the nucleolus was present and was at this stage near the nuclear membrane. Nearer to the necrotic focus the nuclei seemed to have lost their nucleoli, and the chromatin was marginated and presented as an irregularly staining basophilic lining to the nuclear membrane resembling a string of pearls. The remainder of the nucleus was generally uniformly eosinophilic and homogeneous, and no individual inclusions could be identified though the nucleus as a whole had increased in size. Occasional nuclei, however, instead of the uniform eosinophilic background appeared to contain small eosinophilic bodies scattered throughout. Towards the centre of the lesion the nuclei while still larger than normal were somewhat smaller than in the previous stage. The whole nucleus was filled with a more compact, denser homogeneous eosinophilic material and only the nuclear membrane took up the basophilic dye. At this stage the outline of the nucleus was irregular and crenated and some of the inclusions under high power objective showed a more purplish than eosinophilic character. Examination under oil immersion showed that what appeared to be a homogeneous inclusion was really a honeycomb of small round eosinophilic bodies set in a bluish coloured matrix, the whole filling the entire nucleus.

The apparent alternative pathway of development did not appear as clear-cut as that just described. Here again the earliest stage was enlargement of the nucleus, fragmentation of chromatin and loss of basophilic staining, margination of chromatin and

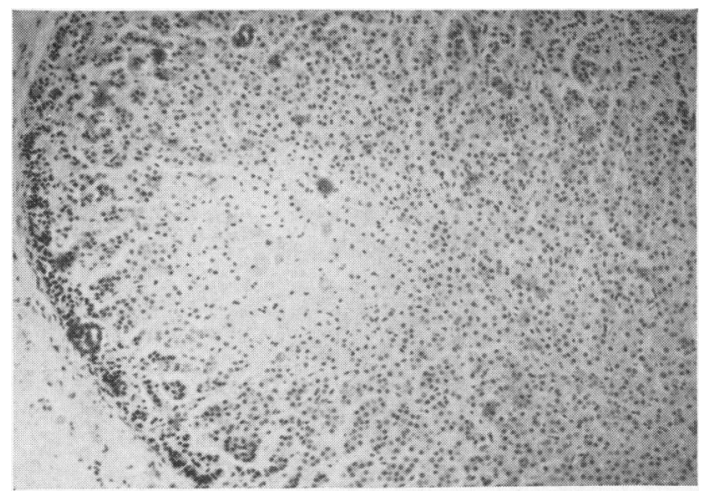

Fig. 7.-Area of necrosis in adrenal cortex. H. and E. $\times 80$.

nucleolus and eventual loss of the latter. The inclusions, however, were slightly different. The first forms seen were cells containing a single, or several, large globular eosinophilic bodies in the nucleus. In some nuclei these were uniform in size, in others larger forms suggesting coalescence were also found. Towards the centre of the lesion inclusions were again single and eosinophilic, but did not fill the enlarged nucleus, and a distinct unstained halo lay between the eosinophilic inclusion body and the basophilic nuclear membrane. Subsequent stages seemed to parallel those already described above.

Hass (1935) described two types of inclusion body, one eosinophilic and one basophilic and traced their development. While two types of inclusions seem to occur in our cases, basophilia of these was not prominent save in the later stages. Whether there are in fact two separate lines of development or whether the nuclear changes described are in reality manifestations of various stages in a single pathway 
of development of virus within the infected nucleus is a matter for conjecture.

Adrenals. No macroscopic lesions were seen in any of these cases, though they have been described in association with disseminated herpes simplex infection and infantile eczema (Brain et al., 1957). Microscopic lesions were seen in five cases (Fig. 7).

Microscopically areas of necrosis were seen in both medulla and cortex. In the cortex there was always a thin rim of normal tissue between the capsule and the necrotic area. The lesion was essentially similar to that in the liver allowing for the differences in the tissue structure. Nuclear inclusions were present, but not with the frequency or variation of those in the liver. The earliest change in the nucleus was increase in size and clearing of the nucleoplasm which showed basophilic stippling due to fragmentation of chromatin. The chromatin became marginated and inclusion bodies appeared in the nucleus showing either as eosinophilic stippling or a homogeneous eosinophilic mass filling the nucleus. Occasionally an unstained halo separated the eosinophilic inclusion from the nuclear membrane.

Spleen. In Cases 7 and 8, though not visible macroscopically, there were small necrotic infarctlike lesions in the spleen.

Although the virus was isolated from these spleens in high titre and not from the blood, the absence of inclusions make it difficult to be certain that the lesions were the result of the herpes simplex virus.

Brain. In all cases with the exception of Case 8, the brains were tense and oedematous and in some congested. Oedema and congestion are not uncommon findings in association with malnutrition. In Case 5 in addition to the oedema and congestion the meninges appeared thickened and gelatinous though no inflammatory exudate was visible.

Microscopically the leptomeninges showed oedema and scattered infiltration by lymphocytic cells. The brain was congested and oedematous but in addition there was minimal lymphocytic perivascular cuffing, suggesting a true meningo-encephalitis.

Other Organs. Other organs examined macroscopically and microscopically included pancreas, lungs, kidneys and myocardium. In none of these were lesions ascribable to the herpes simplex virus found. The trachea and large bronchi showed no macroscopic lesions, but were not examined microscopically. This is an unfortunate omission, as in a subsequent case, not included in this series, typical and extensive lesions have been seen in the trachea and bronchi. The smaller bronchi and bronchioles encountered in sections of the lung showed no nuclear changes in the lining epithelium. The lung parenchyma in all instances was normal.

In the pancreas there was some duct and acinar dilatation with accumulation in the lumina of eosinophilic material; and in some a minor degree of acinar atrophy: these appearances are not infrequently seen in association with kwashiorkor and malnutrition, and a relationship to the herpes simplex infection is unlikely.

Vascular lesions as described by other authors in the liver (Zuelzer and Stulberg, 1952; Williams and Jack, 1955) and in the spleen (Williams and Jack, 1955) were not seen in our cases.

\section{Discussion}

Widespread dissemination of the herpes simplex virus with lesions in internal organs is no new entity (Smith et al., 1941; Wildi, 1951; Quilligan and Wilson, 1951; Florman and Mindlin, 1952; Zuelzer and Stulberg, 1952; France and Wilmers, 1953; Pugh et al., 1954; Williams and Jack, 1955; Brain et al., 1957), and the unusual features of our cases are the older age group in which they occurred and the frequent association with malnutrition.

As far as we are aware similar observations have not been previously recorded in South Africa, although in clinical experience herpetic gingivostomatitis is relatively common in the Union in the 1 to 5-year age group. Whether the number of cases of systemic herpes simplex infection seen in this relatively short period implies a sudden increase of virulence in the local strain of virus, or whether the incidence of overt infection reached epidemic proportions it is impossible to say.

Several authors have noted that the incidence of primary local herpetic infections is higher in the lower socio-economic group (Andrewes and Carmichael, 1930; Burnet and Lush, 1939; Scott, Coriell, Bland and Burgoon, 1952) and that the greatest number of those susceptible to infection are between 6 and 24 months of age (Burnet and Williams, 1939; Scott et al., 1952). The general pattern of infection seen locally substantiates this, and we would suggest that where malnutrition is an accompaniment of poor socio-economic conditions the chances of dissemination of herpes simplex gingivo-stomatitis to internal organs may be increased.

Though no figures are available in South Africa to indicate the ratio of subclinical to clinical infection, Coetzee (1955) has shown that $100 \%$ of the sera of adult Bantu in the Pretoria area had antibodies to the herpes simplex virus. Anderson and Hamilton 
(1949) showed that $100 \%$ of susceptibles in an orphanage in Australia became infected by 22 months of age, whereas McNair Scott et al. (1952), investigating lower income groups attending the out-patients clinic of the Children's Hospital of Philadelphia, found $64 \%$ had antibodies, and Burnet and Lush (1939) reported antibodies in $93 \%$ of persons attending a general hospital. From Coetzee's (1955) figures it would appear that the incidence of infection in the low socio-economic groups in South Africa is maximal.

We wish to stress the high specificity of the naked eye appearances of the liver when the necrotic foci are abundant, and indeed now regard it as diagnostic of disseminated herpes. In retrospect in five out of the eight cases the diagnosis could have been made with the naked eye. The microscopical appearances are also characteristic both in extent and type but focal necroses are not rare in the liver and the diagnosis might well be missed if one did not know of the herpetic lesion and no macroscopic specimens were available. Virus was isolated in high titre from the liver and spleen but not from the blood, and though the splenic lesions are not histologically specific, it is felt that they may well be due to localization of the virus at this site.

Treatment of these cases by other than symptomatic methods presents a difficult problem. Supportive measures and antibiotics are essential and there may be justification for steroid therapy where there is no question of infantile eczema and where dissemination of the virus is suspected. A case may however be advanced for massive gamma-globulin therapy in malnourished children with primary herpes simplex infection as a protective measure against dissemination.

\section{Summary}

Eight cases of disseminated herpes simplex virus infection in children 9 to 16 months of age are reported.

An association between malnutrition and dissemination of the virus is mooted.

Attention is drawn to the highly characteristic liver lesions and the histo-pathology of various organs is described.

Virus isolation was carried out in three cases with titration of virus in several organs in two of these.

The high incidence of infection in the lower socio-economic groups is briefly discussed.

We wish to thank Professor J. G. Thomson, Professor A. Kipps and Dr. C. J. Uys for advice and criticism; Dr. L. Anstey and Dr. C. J. Watson for the, autopsies on Cases 5 and 8; Professor F. Ford for permission to use cases from his wards and Dr. J. F. W. Mostert, Superintendent of the Red Cross Children's Hospital, for permission to publish. Thanks are also due to $\mathrm{Mr}$. B. Todt and Mr. W. Taylor for photographs.

\section{REFERENCES}

Anderson, S. G. and Hamilton, J. (1949). Med. J. Aust. 1, 308. Andrewes, C. H. and Carmichael, E. A. (1930). Lancet, 1, 857. Brain, R. T., Pugh, R. C. B. and Dudgeon, J. A. (1957). Arch. Dis. Childh., 32, 120.

Burnet, F. M. and Lush, D. (1939). Lancet, 1, 629.

and Williams, S. W. (1939). Med. J. Aust., 1, 637.

Coetzee, J, N, (1955). S. Afr. J. Lab. clin. Med., 1, 52.

Florman, A. L. and Mindlin, R. L. (1952). A.M.A. Amer J. Dis. Child., 83, 481 .

France, N. E. and Wilmers, M. J. (1953), Lancet, 1, 1181.

Hass, G. M. (1935). Amer. J. Path., 11, 127.

Melnick, J. L. (1956). In Diagnostic Procedures for Virus and Rickettsial Diseases, 2nd ed. American Public Health Association, New York.

Pugh, R. C. B., Newns, G. H. and Dudgeon J. A. (1954). Arch. Dis. Childh., 29, 60.

Quilligan, J. J. and Wilson, J. L. (1951). J. Lab. clin. Med., 38, 742. Scott, T. F. McN., Coriell, L., Bland, H. and Burgoon, C. F. (1952) J. Pediat., 41, 835.

Smith, M. G., Lennette, E. H. and Reames, H. R. (1941). Amer. J. Path., 17, 55

Wildi, E. (1951). Rev. neurol., 84, 201.

Williams, A. and Jack, I. (1955). Med. J. Aust., 1, 392.

Zuelzer, W. W. and Stulberg, C. S. (1952). A.M.A. Amer. J. Dis. Child., 83, 421 . 